\title{
Connectivity of regional systems of consumer goods reproduction
}

\author{
V.M. Timiryanova \\ Bashkir State University, Ufa, Russia; 79174073127@mail.ru
}

\begin{abstract}
Relevance. The question of how to achieve a more stable economic reproduction and how to expand it is of prime importance as reproduction determines the development of the whole economic system. Due to the constant economic transformations and the so-called 'networkization' of many processes, more research is needed into the spatial organization of reproduction, in particular the intraregional and interregional relationships between its elements. Research objective. This study aims at showing the spatial connections between phases of reproduction on the regional and municipal levels. Data and methods. The study relies on tools and methods of spatial econometric modelling, which includes calculations of univariate and bivariate global and local Moran's indices and diagrams of their dispersion. We constructed an adjacency matrix for Russian regions and municipalities. Overall, our study uses the data on 2,337 municipalities in 84 Russian regions. Results. It was found that the phase of consumption followed by the phases of distribution and exchange have the highest degree of connectivity. Spatial connectivity between the phases was the most pronounced in the case of retail trade and consumption and was much weaker in the case of wholesale trade and production. The analysis of the municipal-level data has revealed some previously undetected relationships between peripheral areas located near regional borders. Conclusions. In this study, we consider reproduction as a spatially organized economic system with interconnected, territorially dependent phases. Such approach provides us with new insights into the ongoing processes in the national economic space.
\end{abstract}

\section{KEY WORDS}

reproduction, regional reproduction, connectivity of economic space, spatial analysis, regional economy

\section{ACKNOWLEDGEMENT}

The research was conducted in fulfillment of the state assignment given by the Ministry of Science and Higher Education of the Russian Federation (code FZWU-2020-0027).

\section{FOR CITATION}

Timiryanova, V.M. (2021) Connectivity of regional systems of consumer goods reproduction. R-economy, 7(1), 5-17. doi: 10.15826/recon.2021.7.1.001

\section{Связанность региональных систем воспроизводства потребительских товаров}

\author{
В.М. Тимирьянова \\ Башкирский государственный университет, Уба, Россия; 79174073127@таil.ru
}

\section{АННОТАЦИЯ}

Актуальность исследования. Проблема достижения устойчивого расширенного воспроизводства относится к ключевым, так как она определяет развитие всей экономической системы. В условиях сетизации и трансформации многих процессов требуют расширения представления о пространственной организации воспроизводства, в том числе в части внутрирегиональных и межрегиональных взаимодействий его субъектов. Цель исследования. Целью исследования является поиск и подтверждение пространственной взаимосвязи между фазами воспроизводства на региональном и муниципальном уровнях. Данные и методы. В исследовании используются инструменты и методы пространственного эконометрического моделирования, в том числе проводится расчет одномерных и бинарных глобальных и локальных пространственных индексов автокорреляции Морана П. и их диаграмм дисперсии. Расчеты проведены по данным 2337 муниципальных образований в разрезе 84 субъектов РФ. На уровне субъектов РФ и муниципальных образований применяется матрица смежности. Результаты. Проведенные расчеты показали, что наиболее связанной является фаза потребления, наименее - фазы распределения и обмена. Наблюдается пространственная связанность фаз воспроизвод-

\section{КЛЮЧЕВЫЕ СЛОВА}

воспроизводство; региональное воспроизводство; связанность экономического пространства; пространственный анализ; региональная экономика

\section{БЛАГОДАРНОСТИ}

Работа выполнена при выполнении государственного задания Министерства науки и высшего образования Российской Федерации (шифр FZWU-2020-0027). 
ства между собой, наиболее ярко проявляющаяся между фазами обмена и потребления. В то же время оборот оптовой торговли характеризуется слабой связанностью с производством и последующим обменом, в том числе пространственной. На уровне муниципальных образований проявляются ранее не отмечаемые при анализе на уровне субъектов РФ внутрирегиональные особенности и связи территорий, расположенных вдоль межрегиональных границ субъектов. Выводы. Исследование воспроизводства как пространственно-организованной экономической системы, характеризуемой не только связью фаз воспроизводства но и их территориальной зависимостью, позволяет по новому взглянуть на протекающие в экономическом пространстве страны процессы.

\section{ДЛЯ ЦИТИРОВАНИЯ}

Timiryanova, V.M. (2021)

Connectivity of regional systems of consumer goods reproduction. R-economy, 7(1), 5-17. doi: 10.15826/recon.2021.7.1.001

\section{Introduction}

Economic space is understood as 'a combination of reproduction cycles of different degrees of localization' (Oleynikova, 2004). In its turn, economic reproduction comprises the following four phases: production, distribution, exchange and consumption. If at least one of these phases is ineffective, it influences the whole cycle, which is why when reproduction occurs in different locations, it inevitably affects the scope and structure of interregional relations between the phases of reproduction necessary to complete the cycle. Closer scrutiny is required of the differences between intermediate goods and consumer goods stemming from the differences in reproduction cycles. The system of reproduction of consumer goods is a subsystem of public reproduction, which integrates different reproduction processes (production, distribution, exchange and consumption) on the micro-level. These processes are necessary for the movement of goods from manufacturers to final consumers. Taking into account the fact that the reproduction of consumer goods fits into the 'nested doll principle' (national <- regional <- local reproduction systems), it makes sense to consider reproduction from a more general perspective as well as on a regional level.

What makes regional reproduction systems unique is their variability and different kinds of participation in the national reproduction system. Reproduction of specific goods has different degrees of localization and, therefore, geographically dispersed places of production and places of consumption are connected through distribution channels within the national reproduction system. 'Each region occupies a certain place in the production of the aggregate product, but the geography of production and consumption can be balanced only on a national scale' (Shniper et al., 1986). An approach focusing on reproduction only in specific regions fails to capture the complexity of this system, which, as shown above, consists of several hierarchically organized phases. Thus, it would be more productive to take a broader perspective and consider the reproduction of consumer goods as a spatially organized economic system.

What makes the research of reproduction systems particularly relevant is the fact that reproduction affects the key characteristics of economic space, connectivity in particular, since the connection between spatially dispersed supply and demand only exists within the process of reproduction. This question is pertinent not only to enterprises interested in expanding their marketing channels and in cost-cutting but also to government agencies involved in decision-making on the placement of manufacturing facilities and trade enterprises. This research can improve the living standards and contribute to revenue growth of businesses located in this or that territory and, therefore, the revenue of this territory. The larger are the disparities in the development of production determined by the concentration of economic activity and regional specialization, the more reliant are the territories on their connections to other regions for meeting the needs of their inhabitants and balancing their living standards with those in other regions.

This study aims at showing the spatial connection between phases of reproduction on the regional and municipal levels. Therefore, we are going to address the following goals: first, we are going to elucidate our understanding of the notion of connectivity in relation to spatially localized reproduction processes; second, we are going to examine the connectivity of territories on the regional and municipal levels by using the relevant data; and, finally, we are going to analyze the gaps in the reproduction cycles related to weak spatial autocorrelations between the values of the indicators characterizing reproduction phases. 


\section{Literature review}

Although there is a vast body of research dealing with the connectivity of economic space, so far no uniform definition of connectivity has been formulated. Connectivity is seen primarily as a characteristic determined by the quantity and intensity of processes (Kuzmina, Tonysheva, 2018), economic relationships (Granberg, 2004), interactions (Polyakova, Simarova, 2014), exchanges (Morgoev, 2006), and the frequency of transactions (Zagitova, 2013). Territories are considered to be connected if there is a movement of goods, resources, information, etc between them. In other words, the larger and the more intensive is the flow of goods, etc to and from the regions, the more connected they are.

There are, however, processes and phenomena such as prices of goods and median wages that are spatially dependent but cannot be measured with the help of flows ${ }^{1}$ (Demidova, 2014). In this respect, the following observation of A.G. Polykova and I.S. Simarova is particularly worthy of interest: 'connectivity as a property of economic space determines the spatial distribution of resources and helps achieve the economic effect of their use' (Polyakova \& Simarova, 2014). T.M. Panina explains that spatial connectivity is characterized by 'the existence and degree of deformations at the intersection of production, distribution, and consumption of gross product', while the level of connectivity can be estimated by looking at the differences 'between the minimal and maximal values of the indicators across the country' (Panina, 2007). Therefore, if we limited our understanding of connectivity to the intensity of interactions, it would mean that we have failed to grasp the complexity of economic space and to see the bigger picture. In reality, economic space encompasses a multitude of divergent relationships, not only between specific territories, but also relationships of systemic, functional, explicit or implicit, direct or indirect nature. Even if one territory is separated from another by a solid wall, each of them will be 'aware' of this fact and, therefore, its development will be affected by the limitation imposed by the neighbour. Another aspect worth mentioning is that connectivity is not usually measured in negative values. We can speak of a total absence of connectivity or different degrees of connectivity

Fayzliev, A.R. (2014). Mathematical methods and models for analyzing the spatial structure of the urban trade system (Dissertation of candidate of economic sciences). Volgograd. (In Russ.). due to the fact that some indicators, for example, the frequency of transactions (Zagitova, 2013) or trade turnover (Morgoev, 2006), do not take negative values.

Studies of migration flows often highlight the positive or negative influence that some territories have on others, which means that this relationship may be direct or inverse. Consequently, the absence of such relationships may be indicative of a 'gap' in the economic space, understood as a substantial disparity between the territories in specific indicators (Zubarevich, 2014). Moderate differences in regional development 'make the processes of formation of an integral regional economic space more dynamic' (Buvaltseva, Sokolovsky, 2008). Considerable differences in the development of regions do not necessarily signify a 'gap' in spatial connectivity: while one region may have a high positive migration level, the level of migration in the neighbouring region may be also high but negative. While one region may have high bankruptcy rates and falling numbers of registered enterprises, its neighbour may demonstrate a significant growth in entrepreneurship, including the growth in the migrant entrepreneur sector. In this case, it may be said that the connection exists, but it is negative. Following this logic, a gap should be seen primarily as a spatial characteristic, as the absence of connection, positive or negative, that is, a change in the indicator in one territory does not depend on the change in this indicator in a neighbouring territory.

Connectivity as a characteristic of economic space is determined by direct and/or inverse dependencies of spatial elements. From the regional perspective, these elements (regions) can be seen as connected if changes in the parameters of one region cause changes in the parameters of another (for instance, a price increase in one region causes a price increase in another; sales growth in one region, a fall in sales in another; a growth in the number of migrants in one region, declining wages in another, and so on). Thus, economic space as a whole is connected if changes in one element of one of the systems constituting this economic space influence all the other systems and lead to changes in other elements.

Within the reproduction system, all the phases - production, distribution, exchange and consumption - are interconnected. The reproduction cycle implies a sequential movement of goods from manufacturing through exchange to consumption, while money and information 
are moving in the opposite direction. When all phases take place in one territory, the cycle becomes closed. If at least one of the phases takes place outside the given territory, the cycle can be described as open and depends upon another territory for its completion. Therefore, within the general economic space, the system for reproduction of consumer goods serves as a link between regional economic systems through 'networkization' (creation of network structures) and integration of geographically scattered enterprises and consumers constituting the reproduction chain. The spatial organization of reproduction is a complex of interacting elements (manufacturing facilities, places of distribution, exchange and consumption) dispersed across space.

The connectivity of regional reproduction systems is determined by direct and/or inverse dependencies between the elements of economic space. These dependencies stem from the geographical dispersion of production facilities, places of distribution, exchange and consumption of goods. Thus, spatial organization of the reproduction of consumer goods is understood as a complex of interconnected, geographically dispersed elements. In regional reproduction systems, inverse territorial dependencies may occur in the case of competitive impact exercised by economic agents located in certain regions on other participants of the same chain located in other regions. In doing so, these economic agents seek to increase their share in the markup profit within the reproduction chain (Hylton, Ross, 2017). Such inverse dependency may be traced by looking at the changes in the territories of production, distribution, exchange and consumption.

Depending on their approach to connectivity, scholars may choose different ways to evaluate it. Studies of territorial connectivity may focus on transport networks (Adzhikova, Shkolnikova, 2016); the volume, structure and effectiveness of resource exchange (goods, labour, etc) (Polozhentseva, 2018; Morgoev, 2006; Kirillova, Kantor, 2010; Tian, Zhang, 2019; Fan, Liu, 2020); the correlation ${ }^{2}$ and regression relationships between GRP and factors of its development (Polyakova, Simarova, 2014b); and agglomeration processes - through expert evaluation of the interactions (Volchkova et al., 2016). Some studies measure the extent of

2 Bakumenko, O.A. (2017). Interregional interaction as a factor in the development of regional socio-economic systems (for example, the North-West Federal District) (Dissertation abstract of candidate of economic sciences). St. Petersburg. (In Russ.) Retrieved from https://search.rsl.ru/ru/record/01006663402. the deformation at the intersection of production, distribution and consumption of gross product by concentrating on the deviations in the region's indicator value from the national average and on the 'differences between the minimal and maximal values of the indicators across the country' (Panina, 2007). These approaches, however, share one major weakness: they fail to see the connectivity of regional reproduction systems as a direct or inverse dependency of elements of economic space. In other words, they fail to see connectivity as a dependency that has both a positive and negative influence on the territories in question. A solution to this problem could be I.S. Simarova's interpretation of interregional connectivity in the light of the balance between the influx and outflux of its determinants (Polyakova, Simarova, 2014). However, her approach does not take into account the position of territories in relation to each other and their proximity. The existing research on the distance between territories (e.g. Bryukhanova, Bartaeva, 2016) is not very productive either. The study of Zemtsov and Baburin (2016) based on gravity models analyzes the economic development of regions and the benefits of their location in relation to each other. These studies, however, put the main emphasis on the economic and geographic conditions of territories and their potential rather than on reproduction processes as such.

Spatial analysis enables us to take full account of the volume, structure and direction of the flows and to investigate the extent of correlation between the relevant variables in specific regions. These methods help us evaluate the spatial correlation of a given indicator or, in other words, measure to what extent the value of a variable of a specific territory relates to the same value in proximate locations. There is a vast body of research, both Russian and international, on the connectivity of processes in economic space (Anselin et al., 2002; Ye, Wei, 2005; Plummer, 2009; Demidova, 2014; Fayzliev, A.R. 2014; Timiryanova et al., 2020). These studies calculate global and local Moran's indices and identify spatial clusters as sets of connected locations. Spatial statistics methodology, which analyzes spatial autocorrelations of indicators, is applied in international studies on manufacturing (Ye, Wei, 2005), distribution (Hylton, Ross, 2017; Tian, Zhang, 2019; Fan, Liu, 2020) and consumption (Khushi et al., 2020). It should be noted, however, that the majority of such studies focus on production. There is evidence that the indicators characterizing produc- 
tion in one territory depend on the development of production in the neighbouring territories (Fabregat and Badia-Miró 2014; Aguilar-Retureta 2016; Díez-Minguela et al. 2018; Lolayekar and Mukhopadhyay 2019). At the same time, there are comparatively few spatial studies examining the connection of wholesale and retail trade with production (Di Berardino et al., 2017).

In this study, we aim to offer a broader look at the connectivity of economic space by focusing on the connectivity of regional systems in all phases of consumer goods reproduction.

\section{Method and Data}

Spatial analysis as a statistical tool to measure the spatial dependency between values of the same variable of different territories was first introduced in the mid-twentieth century by P. Moran (1948) and R. Geary (1954). Spatial analysis was further developed by L. Anselin $(2002,2005)$. The main indicator used to estimate spatial relationships is Moran's I, which estimates the spatial autocorrelation of statistics and shows a linear association between the observation vector and the vector of spatially weighted values of the same indicator in the neighbouring territories. The Moran's statistic is calculated according to the following formula:

$$
\operatorname{Im}_{x}=\frac{N}{\sum_{i} \sum_{j} w_{j}} \frac{\sum_{i} \sum_{j} w_{i j}\left(x_{i}-\bar{x}\right)\left(x_{j}-\bar{x}\right)}{\sum_{i}\left(x_{i}-\bar{x}\right)^{2}},
$$

where $N$ is the number of territorial units; $\bar{x}$ is the mean value of the indicator; $w_{i j}$ are the elements of the spatial weights matrix.

The computed value of Moran's I is compared to the expected value:

$$
E(I)=\frac{-1}{(n-1)} .
$$

Im $>E(I)$ signifies a positive spatial autocorrelation, that is, in general, the observation values in the neighbouring territories are similar; Im $<E(I)$ signifies a negative autocorrelation, that is, in general, the neighboring values are dissimilar; $I m=E(I)$ signifies that observations in the neighbouring territories are not correlated, in other words, it means that the development of these territories is in no way connected to each other and, therefore, we cannot predict the changes in one territory by analyzing the changes in the neighbouring territory.

To find a spatial relationship, we need to use a weights matrix which formalizes the assump- tion that the given territory is connected to its neighbours. There are no rigid rules on how to set spatial weights or identify the neighbours and there is a variety of methods to measure spatial connectivity. The choice of neighbours and spatial weights is not determined exclusively by the geographic considerations (9). Studies show that inverse distance matrices are more preferable for accurate quantitative measurements of connectivity while the results obtained through other kinds of weights matrices usually provide the researchers with more general conclusions, for example, that the territories of interest have a positive or a negative connection or that they are not connected at all (8).

Overall, the spatial weights matrix formalizes the assumption that the territory of interest has a connection with its neighbours. Our analysis used two connectivity matrices to take into account the proximity of Russian regions in relation to each other and municipalities. For both matrices we used only first-order neighbours, that is, those sharing a common border. Regarding Russian regions, the following assumptions were made: the Republic of Crimea borders with Krasnodar region; Sakhalin region, with Primorye, Khabarovsk and Kamchatka regions; the city of Kaliningrad, with St. Petersburg and Smolensk region. The latter assumption seems rather questionable but it allows us to consider the spatial relationships between the areas of Kaliningrad region and at the same time consider the territory as a whole, including the sea and rail links between the regions.

On the municipal level, the proximity of island municipalities was determined by looking at the geographical distance between them. For example, Novaya Zemlya of Arkhangelsk region is considered as a neighbouring location in relation to Zapolyarny District of the Nenets Autonomous Area, which is the closest; Yelizovsky District is considered as a neighbour to Ust-Bolsheretsky District in Kamchatka; Leninsky District and the city of Kerch in the Crimea, as neighbours to Temryuksky District of Krasnodar region; Aleutsky District, as a neighbour to Ust-Kamchatsky District in Kamchatka; and, finally, city districts Yuzhno-Kurilsky, Kurilsky, and Korsakovsky, as neighbours to Severo-Kurilsky city district of Sakhalin region and in relation to each other.

Indicator values of the neighbouring territories are used to construct a Moran scatter plot in order to visualize the distribution of values of the given indicator against its spatially lagged 
values. Its horizontal axis is based on the values of a chosen indicator for a certain location while the vertical axis is based on the weighted average of the corresponding observations for all the neighbouring territories in accordance with the chosen weights matrix. Moran's I is equivalent to the slope of the regression line in the diagram.

Apart from the univariate spatial correlation, we also estimated the bivariate correlation (22) with the help of the bivariate Moran's I. The fundamental difference between the bivariate Moran's I from Global Moran's I is that in the case of the former, the spatial lag is related to another variable. The bivariate spatial correlation measures the correlation of a certain variable of one territory and another variable of the neighbouring territories.

$$
I b m_{x}=\frac{N}{\sum_{i} \sum_{j} w_{j}} \frac{\sum_{i} \sum_{j} w_{i j}\left(x_{i}-\bar{x}\right)\left(y_{j}-\bar{y}\right)}{\sum_{i}\left(x_{i}-\bar{x}\right)^{2}},
$$

where $N$ is the number of territorial units; $\bar{x}$ mean of indicator $x$; $\bar{y}$ mean of indicator $y ; w_{i j}$ are the elements of the spatial weights matrix.

For each territory we calculated Local Moran's I (LISA - Local Index Spatial Autocorrelation) to identify local clusters and spatial outliers:

$$
L_{\text {Imi }}=N \frac{\left(x_{i}-\bar{x}\right) \sum_{i} \sum_{j} w_{i j}\left(x_{i}-\bar{x}\right)}{\sum_{i}\left(x_{i}-\bar{x}\right)^{2}} .
$$

$L_{l m i}<0$ signifies a negative spatial autocorrelation, meaning that the territory differs significantly from its neighbours (outlier). $L_{l m i}>0$ signifies a positive spatial autocorrelation, meaning that the territory is similar to neighbours (cluster). Statistical significance of the spatial autocorrelation coefficients is determined with the help of the standard Wald test.

The values of the Local Moran's I and their statistical significance are used to identify the following cluster cores among the given territorial units:

1. High-High locations are those that have relatively high values in the given indicator and are surrounded by locations with similarly high values in the same indicator. The spatial autocorrelation is positive.

2. Low-Low locations are those that have relatively low values in the given indicator and are surrounded by locations with similarly low values in the same indicator. The spatial autocorrelation is positive.
3. High-Low locations are those that have relatively high values in the given indicator and are surrounded by territories with relatively low values in the same indicator. The spatial autocorrelation is negative.

4. Low-High locations are those that have relatively low values in the given indicator and are surrounded by territories with relatively high values in the same indicator. The spatial autocorrelation is negative.

With the help of this method, we can study and identify territories with particularly high levels of spatial dependency.

Analysis of spatial relationships for different reproduction phases can be conducted on the regional as well as municipal levels by using the data aggregated by the Federal State Statistics Service of Russia (https://www.gks.ru/):

- production phase:

1) regional level: the volume of shipped own produced goods, executed works and services for the type of economic activity 'Manufacturing';

2) municipal level: the volume of shipped own produced goods, executed works and services (excluding small businesses);

- phase of distribution and exchange:

1) regional level: the wholesale turnover with adjustment for the output of the unobservable economic activities; retail turnover;

2) municipal level: total food products sold within the boundaries of a given municipality or city district. This indicator reveals the disparities between Russian municipalities in terms of their performance in specific indicators (above) as well as in terms of the connectedness of these values $(\text { below })^{3}$

- consumption phase:

1) regional level: average household consumption expenditures per household member (food, alcohol beverages, non-foods); per capita income;

2) municipal level: social payments and taxable income.

This study relies on the data on 2,320 municipalities (city districts and municipal districts) of 85 Russian regions. The calculations for municipalities do not include the city of Sevastopol and a number of closed towns due to the lack of access to these data.

3 There are currently no statistical data on retail turnover for the majority of municipalities, which is why we considered only food products turnover. 


\section{Results}

Global Moran's I provides us with a general picture of connectivity of Russian territories. The indicators were recalculated per capita to exclude the scale factor of these territories' economies. These calculations showed that in different reproduction phases, there is a different degree of connectivity of territories. High Moran's I scores were obtained in indicators characterizing consumption on the regional and municipal levels. A positive Moran's I points to the fact that there is a strong direct correlation between the values of neighbouring regions in the indicators reflecting consumption expenditures and income. Due to the lack of data on consumption expenditures in municipalities, we used social payments and taxable income because income and spending are usually related. This figure indicates a significant connection between the territories, that is, the income levels in the neighbouring territories are similar. This can be explained the following way: there are usually small distances between the municipalities and, therefore, the significant disparities between entrepreneurial income and wages are offset by migration, that is, a certain spatial balance is maintained (27).

In general, a similar picture is observed for the volumes of shipped goods in neighbouring territories. On the regional level, Global Moran's I in 2010-2019 varied from 0.29 to 0.39 ; on the municipal level, it was lower, which shows a certain degree of fragmentation in the way production is organized in cities and districts. Municipal-level analysis brings to light several interesting aspects: for example, more pronounced direct and inverse dependencies. This matter requires further investigation. The phases of distribution and exchange determined by the performance results of trade companies have the lowest degrees of connectivity.

Maps in Figure 1 show the disparities between Russian regions in selected indicators (right) and the connectivity of these values (left). Taking into account the high heterogeneity of these values, in the maps on the right, regions are divided not into equal intervals within the given range but are grouped according to the criterion of the minimum intragroup differentiation. This way regions with similar results can be grouped together.

The results of clustering based on the calculations of local Moran's I are shown on the left. The division into four types of clusters enables us to identify territories with direct or inverse connections. For instance, there is a direct positive correlation of the volume of shipped goods and wholesale turnover between Moscow and Moscow region. At the same time, Kaluga region, which is located nearby, belongs to the Low-High cluster, which shows that to the west of Moscow region there is a territory with an inverse dependency in terms of wholesale trade. This can be seen from the fact that although Kaluga region has a low value in this indicator, the surrounding regions have higher values. Thus, we are dealing here with an outlier in which a low value is surrounded by high values. North Caucasian regions in all the indicators and phases of reproduction have low values. Virtually the entire territory of the North Caucasus belongs to the Low-Low type, which means that Russian regions located in this federal district, share the same characteristics and face the same problems, in other words, they can be seen as interconnected regional systems of consumer goods reproduction.

Regarding household consumption expenditures, we can identify a large zone of the HighHigh type in the north-west of the country. It can be concluded that this group of Russian regions share a number of common characteristics, including higher prices for consumer goods, which affects the general estimation of consumption expenditures of households.

Our calculations give us a general idea of the spatial organization of regional reproduction systems. Moving to another level of data aggregation, we can see that these connections are not as simple as they may seem and connectivity is found only in some of the regions. Figure 2 illustrates the data on municipalities in the indicator 'Total Food Products Sold within the Boundaries of a Municipality or City District'.

These data demonstrate the disparities between Russian municipalities in terms of their performance in specific indicators (above) as well as in terms of the connectedness of these values (below). The figures of total foods sold show only a part of the retail trade turnover, which is why if we compare Figure 1 and 2, we will see that the values of total foods sold (Fig. 2) agree with the data on retail trade and consumption (Fig. 1) On the other hand, as Figure 1 illustrates, some Russian regions that are generally seen as connected can now be also considered connected on the level of specific municipalities (for example, the Republic of Dagestan and Altai region). 
Volume of shipped own produced goods, executed works and services for the type of economic activity 'Manufacturing'
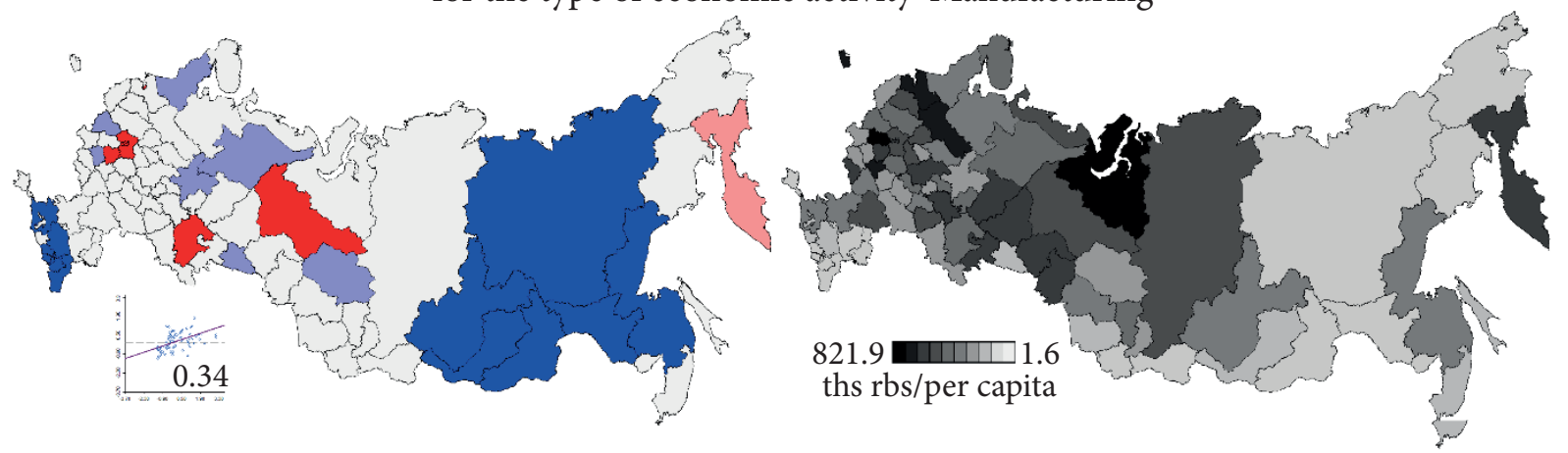

Wholesale turnover with adjustment for the output of the unobservable economic activities (organizations and enterprises specializing on wholwsale trade)
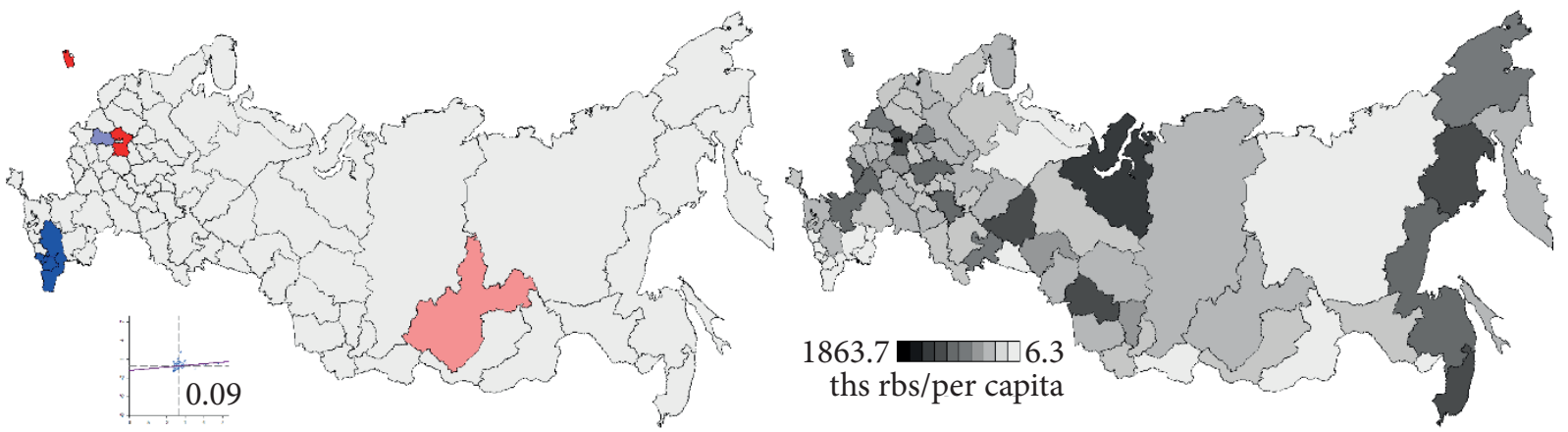

Retail trade turnover
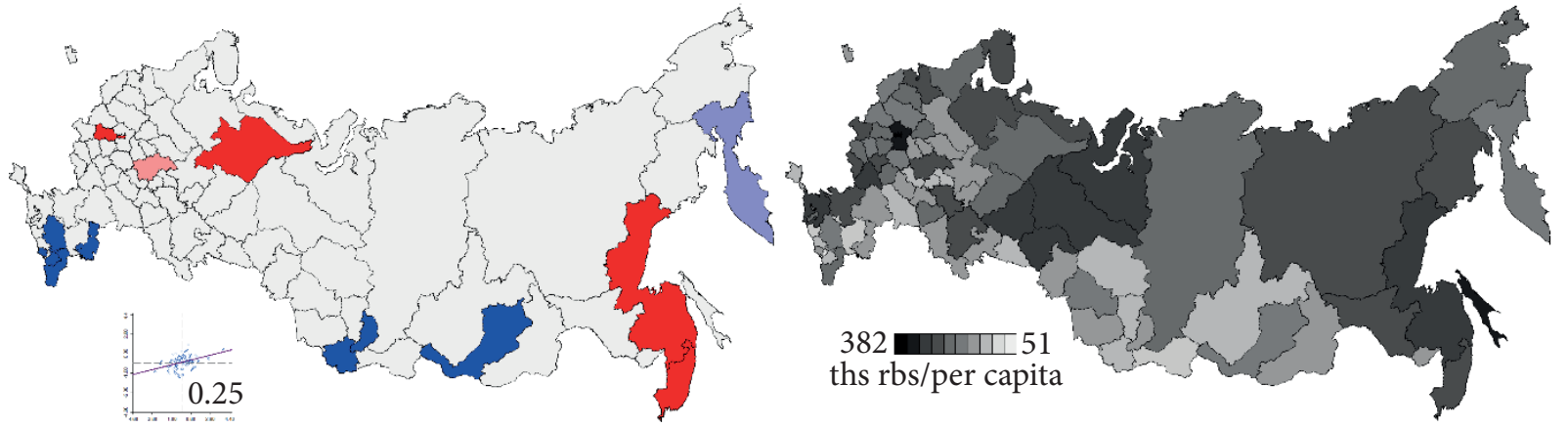

Household consumption expenditures (foods, alcoholic beverages, non-foods)
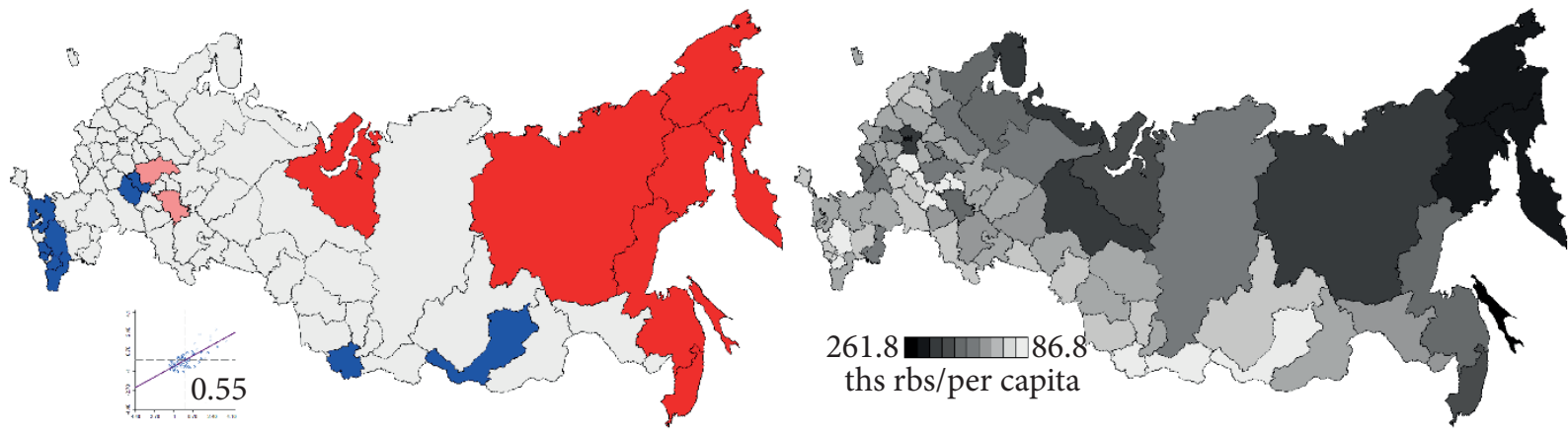

-High-High $\square$ Low-Low $\square$ Low-High $\square$ High-Low

Figure 1. Map of territorial clusters and graph of Global Moran's I on the left, actual distribution of Russian regions in per capita indicators characterizing reproduction phases on the right, 2018 
Similar calculations for the volume of shipped own-produced goods, social payments, and taxable income on the municipal level have revealed spatial 'hot' (concentration of high values) and 'cold' spots (concentration of low values), including those that went undetected previously. We found, for instance, that in Tomsk region, which was previously attributed to the Low-High Cluster in the indicator 'Volume of Shipped Goods', there are actually three clusters of municipalities - High-High in the west, Low-High in the east, and Low-Low in the centre. In all the indicators characterizing different reproduction phases in areas located near the borders of Russian regions, we can observe many territorial clusters of the Low-Low type, undetected previously. This fact points to the problems shared by peripheral areas in these regions.

In general, on the municipal level, the position of clusters of the High-High type in the indicator 'Social Payments and Taxable Income' is in conformity with their positions on the regional level in the indicator 'Household Consumption Expenditures'. These clusters occupy almost the whole of the country's north-west. Similarly, we have found coinciding zones of the Low-Low type in the North Caucasian Federal District. The resulting picture of the spatial organization of income and consumption expenditures of households brings to light the system of horizontal and vertical connections in economic space. On the one hand, we can see the connection between

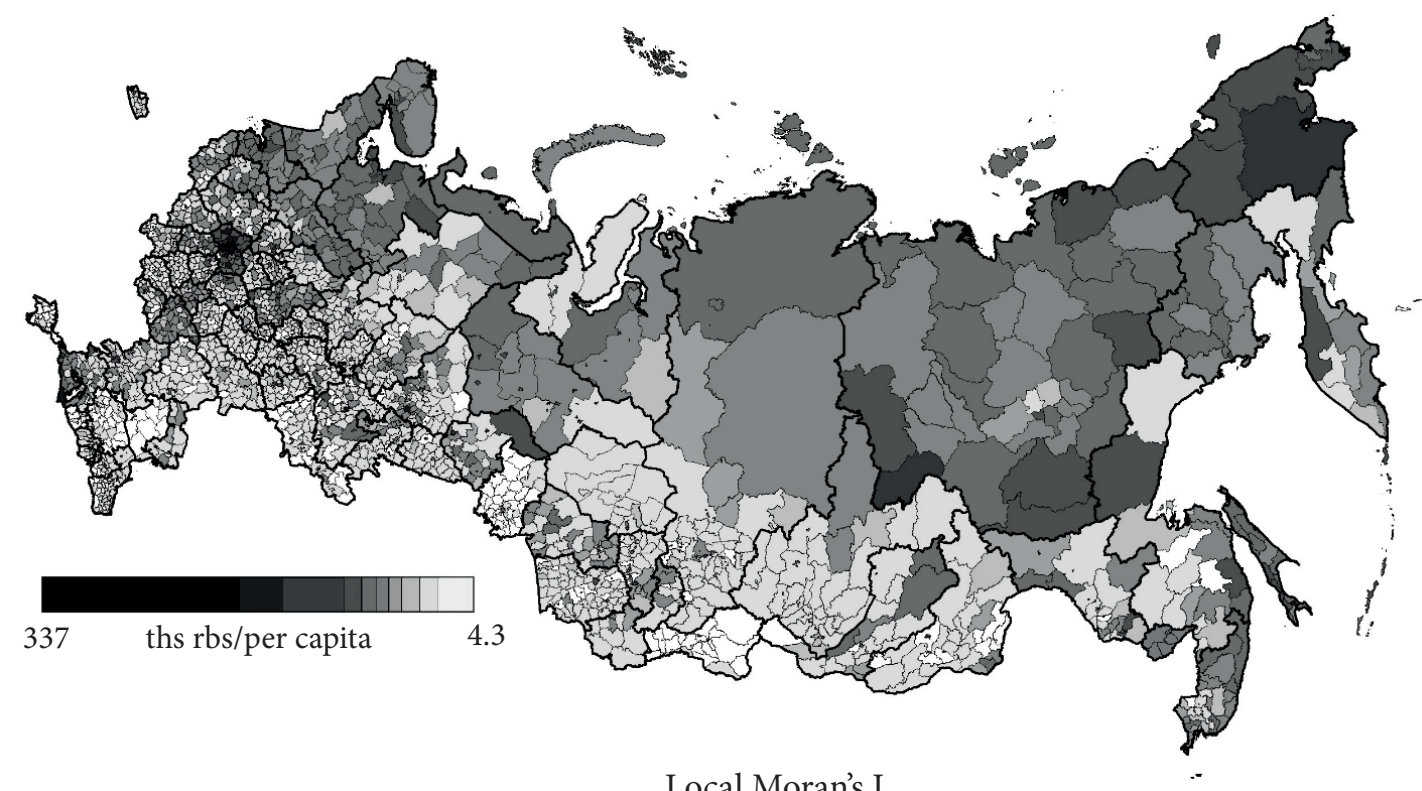

Local Moran’s I

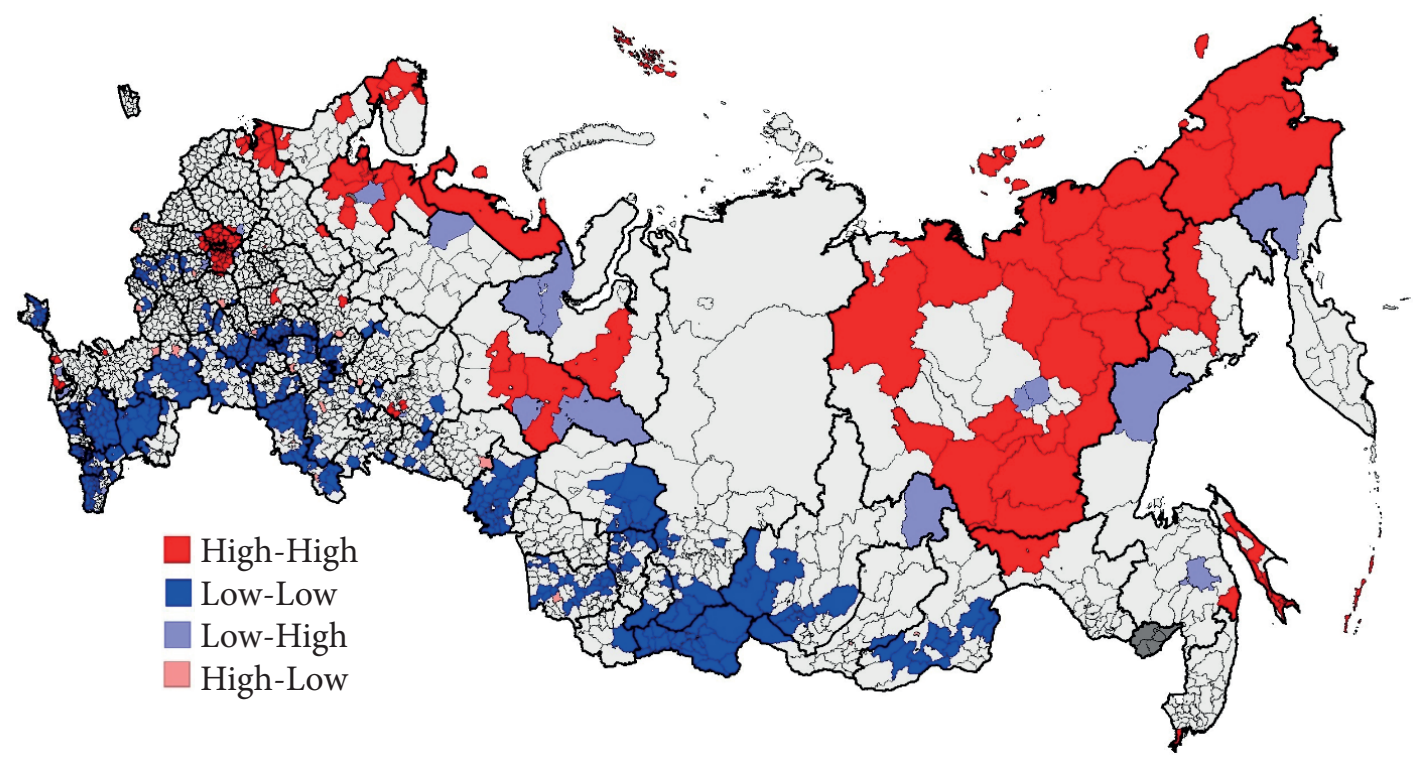

Figure 2. Total foods sold per capita within the boundaries of a municipality or city district, 2018 
income and expenditures highlighted by many researchers; on the other hand, we see the territorial connections related to income generation and income distribution. More detailed data can reveal some more previously undetected connections between the municipalities located near the interregional borders and help identify those Russian regions where connectivity is observed in only a part of their territories.

Our analysis has shown that in the way similar to regional disparities, connectivity can manifest itself differently in different phases of reproduction. Analysis of horizontal connections gives us a somewhat simplified picture of the spatial organization of regional reproduction systems. Within the reproduction system, there is a cyclic succession of interconnected phases of production, distribution, exchange and consumption. In general, within the economic space, there is a cyclic turnover of goods, money, capital, and so on. Enterprises use some of their profits to pay their employees, while the latter, in their turn, spend a part of the income to buy products manufactured by enterprises. As we follow the reproduction cycle, however, we can see that while goods are moving from one phase to the next, they are also moving between the regions. Wholesale trade in the phases of distribution and exchange is particularly illustrative in this respect: manufactured goods flow into distribution centres and then via retail chains move to places of consumption. These links can be identified with the help of cross-sectional spatial analysis, by comparing indicator values within one phase of reproduction of one territory with the indicator values characterizing another phase of reproduction in the neighbouring territories. Such analysis can be conducted by computing the bivariate Moran's I.

Our analysis of cross-connections took into account phases in the reproduction chain (see Table 1): for example, the volume of manufactured goods distributed through the wholesale system and, therefore, the wholesale trade turnover of a given territory may depend on the supply of goods by firms located in this territory as well as in the neighbouring territories.

The calculation of the bivariate Moran's I has shown that the wholesale trade turnover is connected with the reproduction in the adjacent territories (Moran's I, 0.22-0.27). There is a direct connection between Russian regions: the development of wholesale trade contributes to the growth in production as the marketing channels are expanded. Analysis of the inverse connection between the development of wholesale trade and the development of production in the neighbouring territories has shown that this connection is also positive. Moran's I varies between 0.14 and 0.19 in

Table 1

Global univariate and bivariate Moran's indices

\begin{tabular}{|c|c|c|c|c|c|c|}
\hline Year & 2010 & 2012 & 2014 & 2016 & 2018 & 2019 \\
\hline \multicolumn{7}{|l|}{ Univariate Moran's I } \\
\hline $\begin{array}{l}\text { Volume of shipped own-produced goods, executed works and services per capita } \\
\text { for the type of economic activity 'Manufacturing' }\end{array}$ & 0.31 & 0.31 & 0.38 & 0.38 & 0.34 & 0.35 \\
\hline $\begin{array}{l}\text { Wholesale turnover with adjustment for the output of the unobservable economic } \\
\text { activities (for organizations whose main type of economic activity is identified as } \\
\text { 'Wholesale Trade') }\end{array}$ & 0.18 & 0.13 & 0.06 & 0.09 & 0.09 & 0.12 \\
\hline Retail turnover & 0.23 & 0.19 & 0.19 & 0.20 & 0.25 & 0.27 \\
\hline Per capita income & 0.45 & 0.43 & 0.43 & 0.44 & 0.45 & 0.46 \\
\hline \multicolumn{7}{|l|}{ Bivariate Moran's I } \\
\hline \multicolumn{7}{|c|}{ Volume of shipped own-produced goods, executed works and services per capita for the type of economic activity 'Manufacturing' } \\
\hline $\begin{array}{l}\text { Wholesale turnover with adjustment for the output of the unobservable economic } \\
\text { activities (for organizations whose main type of economic activity is identified as } \\
\text { 'Wholesale Trade') }\end{array}$ & 0.17 & 0.14 & 0.17 & 0.18 & 0.18 & 0.19 \\
\hline Retail turnover & 0.11 & 0.11 & 0.19 & 0.20 & 0.22 & 0.22 \\
\hline \multicolumn{7}{|c|}{$\begin{array}{c}\text { Wholesale turnover with adjustment for the output of the unobservable economic activities (for organizations whose main } \\
\text { type of economic activity is identified as 'Wholesale Trade') }\end{array}$} \\
\hline $\begin{array}{l}\text { Volume of shipped own-produced goods, executed works and services per capita } \\
\text { for the type of economic activity 'Manufacturing' }\end{array}$ & 0.24 & 0.22 & 0.25 & 0.24 & 0.25 & 0.27 \\
\hline Retail turnover & 0.16 & 0.16 & 0.17 & 0.19 & 0.20 & 0.20 \\
\hline \multicolumn{7}{|l|}{ Retail turnover } \\
\hline Per capita income & 0.25 & 0.22 & 0.19 & 0.23 & 0.25 & 0.25 \\
\hline
\end{tabular}


2010-2019. Thus, wholesale trade influences production and vice versa. The relationship between wholesale and retail trade is also bidirectional: on the one hand, wholesaling is necessary for the overall distribution of goods, including retail chains in nearby regions, on the other, retail trade relies on the goods supplied by wholesale firms in neighbouring regions. Our calculations of the bivariate Moran's I have shown that the former connection is stronger than the latter. In 20102019, Moran's I was 0.16-0.2. In its turn, the retail trade turnover is related to the level of income in neighbouring regions $(0.19-0.25)$, which may be indicative of the fact that the money earned in one region may be spent in a neighbouring region due to higher levels of trade services.

We also analyzed the dynamics of connectivity and detected a decline in connectivity in 2013-2015, which affected all the cross-connections of the indicators. Thus, we can conclude that within the general economic space, there was a decline in cross-connectivity of regional reproduction systems. Connectivity in a regional reproduction system may change simultaneously in all phases of reproduction due to the factors that affect the entire system.

\section{Conclusions}

The connectivity of regional reproduction systems is determined by direct and/or inverse dependencies of elements of economic space. These dependencies occur because places of production, distribution, exchange and consumption of goods are dispersed across space.

The highest degree of connectivity is characteristic of the consumption phase, the lowest, of the phases of distribution and exchange. The lowest degree of connectivity of territories is observed for the wholesale trade turnover. It results from the high concentration of wholesale trade in the Central Federal District - over 60\%. Cross-sectional analysis has shown that the wholesale trade turnover depends on manufacturing in neighbouring locations while the retail trade turnover spatially correlates with the income levels in the neighbouring regions. The resulting values, however, are quite low. Thus, the wholesale trade sector, whose functions include ensuring a smooth flow of locally produced goods to markets, limits the possibilities of regional reproduction cycles. In fact, as wholesale trade tends to be more sluggish in regions and its spatial connectivity in some of the local reproduction cycles (mostly those formed by small local businesses) is low, supply channels become constricted or, at worst, disruptions of the supply chain may occur.

The results of spatial autocorrelation analysis depend on the level of data aggregation. Heterogeneity and connectivity are more pronounced if the analysis uses municipal-level data. Regional-level estimates are more conducive to generalizations but they fail to reveal the diversity of connections and dependencies, including those in peripheral areas near interregional borders. Therefore, for a more insightful research on the spatial connectivity of localized reproduction phases, analysis should shift from the regional to municipal-level data. In this case, we can gain a better understanding of the regional and interregional connectivity, in particular the core-periphery connections and the connections between the centres and peripheral areas of regions.

Another important avenue for future research may deal with the relationship between the heterogeneity of space and its connectivity. This question is still open for debate. There is evidence that for the same level of variance of an indicator, spatial connectivity can be high or virtually absent (Anselin, 2005). In territories with high heterogeneity, however, spatial connectivity tends to be lower (Timiryanova et al., 2019). In further research, the range of measures and observation units may be expanded to provide a more indepth understanding of spatial connectivity.

\section{References}

Adzhikova, A.S., \& Shkolnikova, N.N. (2016). The integration of regions and quality of economic space. Science Journal of Volgograd State University. Economics, 2 (35), 18-25. (In Russ.) doi: 10.15688/jvolsu3.2016.2.2.

Aguilar-Retureta, J. (2016). Regional Income Distribution in Mexico: New LongTerm Evidence, 1895-2010. Economic History of Developing Regions, 31(2-3), 225-252. doi: $\underline{10.1080 / 20780389.2016 .1175298 .}$.

Anselin, L. (2005). Exploring Spatial Data with GeoDa: A Workbook. Urbana. 51.

Anselin, L., Syabri, I., \& Smirnov, O. (2002). Visualizing Multivariate Spatial Correlation with Dynamically Linked Windows. Computing Science and Statistics, 22. Retrieved from 
https://www.semanticscholar.org/paper/Visualizing-Multivariate-Spatial-Correlation-with-Mirnov/4e34bd70317377971ba8df7259288b972ad6a239.

Beaudry, P., Green, D.A., \& Sand, B.M. (2014). Spatial equilibrium with unemployment and wage bargaining: Theory and estimation. Journal of Urban Economics, 79, 2. doi: 10.1016/j.jue.2013.08.005.

Bryukhanova, V.B., \& Bartaeva, D.C. (2016). Methods of analysis of the regional spatial development. Ekonomika: vchera, segodnja, zavtra = Economy: Yesterday, Today, Tomorrow, 6, 12A, 347-357. (In Russ.) Retrieved from https://elibrary.ru/item.asp?id=29077465.

Buvaltseva, V.I., \& Sokolovsky, M.V. (2008). The unevenness of regional development: features of manifestation and directions of overcoming. Siberian Financial School, 3, 43-48. (In Russ.) Retrieved from https://elibrary.ru/item.asp?id=11607588.

Demidova, O.A. (2014). Spatial-autoregressive model for the two groups of related regions (eastern and western parts of Russia). Applied Econometrics, 2 (34), 19-35. (In Russ.) Retrieved from https://ideas.repec.org/a/ris/apltrx/0235.html.

Di Berardino, C., D’Ingiullo, D., \& Sarra, A. (2017). Distributive trade and regional productivity growth. The Service Industries Journal, 37(13-14), 833-857. doi: 10.1080/02642069.2017.1359261.

Díez-Minguela, A, Martinez-Galarraga, J., \& Tirado-Fabregat, D. A. (2018). Spatial Patterns of Regional Income Inequality Then and Now. Regional Inequality in Spain, 129-148. doi: 10.1007/978-3-319-96110-1 6.

Fabregat, D., Tirado, A., \& Badia-Miry, M. (2014). New Evidence on Regional Inequality in Iberia (1900-2000). Historical Methods: A Journal of Quantitative and Interdisciplinary History, 47, 180-189. doi: 10.1080/01615440.2014.955232.

Fan, X., \& Liu, H. (2020). Global supply chain shifting: A macro sense of production relocation based on multi-regional input-output table. Economic Modelling, 94, 672-680. doi: 10.1016/j.econmod.2020.02.009.

Geary, R. (1954). The continiguity ratio and statistical mapping. The Incorporated Statistician, 5, 115-145. doi: $10.2307 / 2986645$.

Granberg, A.G. (2004). Fundamentals of the regional economy. $4^{\text {th }}$ ed. Moscow: Publishing house of the Higher School of Economics. (In Russ.).

Hylton, P.J., \& Ross, C.L. (2017). Agglomeration economies' influence on logistics clusters' growth and competitiveness. Regional Studies, 52(3), 350-361. doi: 10.1080/00343404.2017.1327708.

Khushi, S., Ahmad, S.R., Ashraf, A., \& Imran, M. (2020). Spatially analyzing food consumption inequalities using GIS with disaggregated data from Punjab, Pakistan. Food Security. doi: $\underline{10.1007 /}$ s12571-020-01057-4.

Kirillova, A.S., \& Kantor, O.G. (2010). Regional development and quality of an economic space. Region: Economics and Sociology, 3, 57-80. (In Russ.) Retrieved from http://recis.ru/index.php/region/index/2010.

Kuzmina, N.L. \& Tonysheva, L.L. (2018). Spatial organization of the economic activity of the region: the essence, forms, transformation. Regionalnye problemy preobrazovanija ekonomiki $=R e-$ gional Problems of Transforming the Economy, 9, 118-126. (In Russ.) Retrieved from https://www. elibrary.ru/item.asp?id=36533645.

Lolayekar, A.P., \& Mukhopadhyay, P. (2019). Spatial Dependence and Regional Income Convergence in India (1981-2010). GeoJournal, 84, 851-864. doi: 10.1007/s10708-018-9893-0.

Moran, P. (1948). The interpretation of statistical maps. Journal of the Royal Statistical Society, Series B, 10, 243-251.

Morgoev, B.T. (2006). Parametritie Optimization of Asymmetrical Development of Russian Economic Sphere. Filosofija hozjajstva = Business Philosophy, 3, 180-190. (In Russ.).

Oleynikova, I.N. (2004). The reproduction process in the regional economy: an innovative component and a management mechanism (structural aspect) (Ed. Yu.S. Kolesnikov). North Caucasus. Research institute econ. and social growth problems. state un-that. Rostov on the Don. (In Russ.). Retrieved from https://www.elibrary.ru/item.asp?id=19751403.

Panina, T.M. (2007). Management of the spatial organization of capital in the socio-economic system (Doctoral dissertation). St. Petersburg. (In Russ.).

Plummer, L.A. (2009). Spatial Dependence in Entrepreneurship Research. Organizational Research Methods, 13(1), 146-175. doi: 10.1177/1094428109334199. 
Polozhentseva, J.S. (2018). Quantitative assessment of the development level of interregional relationship of the economic space. Innovacionnaja jekonomika: perspektivy razvitija i sovershenstvovanija = Innovative Economy: Prospects for Development and Improvement, 3 (29), 116-128. (In Russ.) Retrieved from https://elibrary.ru/item.asp?id=35039976.

Polyakova, A.G., \& Simarova, I.S. (2014). Substantiation of regional development taking into account the connection of economic space. Tyumen: Tyumen State Oil and Gas University. (In Russ.).

Polyakova, A.G., \& Simarova, I.S. (2014b). Region economical space and territory development: the evaluation of cohesion forces activity. Journal of Applied Economic Research = Bulletin of Ural Federal University. Series Economics and Management, 2, 48-60. (In Russ.) Retrieved from https:// journalaer.ru/en/archive/journal/61/single/.

Shniper, R.I., Voevoda, I.N., \& Guzner, S.S. (1986). Regional program and principles of its development: Issues of intersectoral interaction. Novosibirsk: Science. (In Russ.).

Tian, X., \& Zhang, M. (2019). Research on Spatial Correlations and Influencing Factors of Logistics Industry Development Level. Sustainability, 11(5), 1356. doi: 10.3390/su11051356.

Timiryanova, V., Grishin, K., \& Krasnoselskaya, D. (2020). Spatial Patterns of Production-Distribution-Consumption Cycle: The Specifics of Developing Russia. Economies, 8(4), 87. doi: 10.3390/ economies8040087.

Timiryanova, V.M., \& Yusupov, K.N. (2019). Spatial and hierarchical aspects in the management of municipalities. Ufa: Aeterna. (In Russ.).

Volchkova, I.V., Danilova, M.N., Podoprigora, Yu.V., Seliverstov, A.A., Ufimtseva, E.V., \& Shadeiko, N.R. (2016). Approaches to the assessment of coherence of social and economic space of agglomeration. Twelfth Fall Conference in Akademgorodok "Modern Issues of Economics and Sociology". Novosibirsk. (In Russ.) Retrieved from https://www.ieie.su/assets/ysc2016/files/volchkova-iv danilova-mn podoprigora-yuv seliverstov-aa ufimceva-ev shadejko-nr.pdf.

Ye,X., \& Wei, Y.D. (2005). Geospatial Analysis of Regional Development in China: The Case of Zhejiang Province and the Wenzhou Model. Eurasian Geography and Economics, 46 (6), 445-464. Retrieved from https://link.springer.com/article/10.1007/s12061-016-9203-5.

Zagitova, L.R. (2013). Transformation of regional economic space in modern Russia. Gorizonty ekonomiki = Economic horizons, 4 (9), 80-82. (In Russ.) Retrieved from https://elibrary.ru/item.as$\mathrm{p} ? \mathrm{id}=19832474$.

Zemtsov, S.P., \& Baburin, V.L. (2016). Assessing the Potential of Economic-Geographical Position for Russian Regions. Ekonomika regiona = Economy of Region, 1, 117-138. (In Russ.).

Zubarevich, N.V. (2014). Economic imbalances in the development of Russian regions and municipalities: the scale, dynamics, and possibilities of reduction. Annual report of the Franco-Russian Analytical Center. Paris: Observo. (In Russ.) Retrieved from https://publications.hse.ru/chapters/134874459.

\section{Information about the author}

Venera M. Timiryanova - Candidate of Sciences (Economics), Senior Researcher, Institute of Economics, Finance and Business, Bashkir State University (3/4, Karl Marx St., Ufa, Bashkortostan, 450076, Russian Federation); e-mail: 79174073127@mail.ru

ARTICLE INFO: received September 14, 2020; accepted November 25, 2020

\section{Информация об авторе}

Тимирьянова Венера Маратовна - кандидат экономических наук, доцент, старший научный сотрудник, зам. зав. лаборатории исследования социально-экономических проблем регионов по научной работе, Башкирский государственный университет (Россия, 450076, Уфа, ул. Карла Маркса, 3/4); e-mail: 79174073127@mail.ru

ИНФОРМАЦИЯ О СТАТЬЕ: дата поступления 14 сентября 2020 г.; дата принятия к печати 25 ноября 2020 г. 